\title{
Spermatozoal capacitation of pink shrimp Farfantepenaeus paulensis
}

\author{
André Braga $^{\text {a,* }}$, Luiz A. Suita de Castro ${ }^{\text {b }}$, Luís H. Poersch ${ }^{\text {a }}$, Wilson Wasielesky ${ }^{\text {a }}$ \\ a Marine Station of Aquaculture, Oceanography Institute, Federal University of Rio Grande, C.P. 474, Rio Grande (RS) 96201-900, Brazil \\ b Immunology and Electronic Microscopy Laboratory, Brazilian Enterprise for Agricultural Research, C.P. 403, Pelotas (RS) 96001-970, Brazil
}

\section{A R T I C L E I N F O}

Article history:

Received 6 March 2014

Received in revised form 31 March 2014

Accepted 11 April 2014

Available online 18 April 2014

\section{Keywords:}

Farfantepenaeus paulensis

Reproduction

Closed thelycum

Spermatozoa

Capacitation

Ultrastructure

\begin{abstract}
A B S T R A C T
The present study evaluated spermatozoal capacitation in Farfantepenaeus paulensis. This process has direct applications in aquaculture, and it consists of the ionic, biochemical and morphological changes during the period that the spermatophore is stored or adhered to the thelycum. These changes make the spermatozoa capable of fertilization. The morphological changes of spermatozoal capacitation have been previously investigated only in sicyoniids and open-thelycum penaeids. Thus, this study is the first morphological account of a closedthelycum penaeid. F. paulensis broodstock were captured offshore in southern Brazil, and spermatophores were collected from the terminal ampoule and from the thelycum of sexually mature females that had naturally copulated. The ultrastructure of the spermatozoal capacitation was investigated via transmission electron microscopy. Spermatozoa of $F$. paulensis show the following changes related to capacitation: (1) the chromatin became less condensed; (2) the acrosomal region became more electron-dense (3) the acrosomal cap became less concave; and (4) the subacrosomal region became much more electron-dense. These results demonstrate that the morphological changes in capacitated spermatozoa of $F$. paulensis are similar to those previously reported for open-thelycum penaeids, i.e., Litopenaeus species. Further studies on the capacitation process are required, especially to evaluate the interaction between biochemical and morphological changes. Such research could be useful for developing biotechnologies that will allow spermatozoal induction without storing the spermatophore in the thelycum and therefore allow in vitro larval production.
\end{abstract}

(c) 2014 Elsevier B.V. All rights reserved.

\section{Introduction}

Spermatozoal capacitation is the process in which a sperm cell undergoes ionic, biochemical and morphological changes after a period of contact with the female body. These changes equip spermatozoa with fertilization capacity. Capacitation happens in both invertebrates and vertebrates (Visconti et al., 1995; Wikramanayake et al., 1992). In shrimp, capacitation has been observed in species with open thelyca, in which the spermatozoa contained in spermatophore adhere to the outside of a female's body (Alfaro et al., 2007).

Spermatozoal capacitation has been evaluated in vitro in a few commercially important shrimp species, e.g., Sicyonia ingentis, Litopenaeus occidentalis, Litopenaeus vannamei, Litopenaeus stylirostris, Trachypenaeus byrdi and Xiphopenaeus riveti (Alfaro et al., 2003, 2007; Wikramanayake et al., 1992). For example, in vitro fertilization rates are lower when spermatophores are collected from the terminal ampoule than when spermatophores are previously stored in the thelycum (Alfaro et al., 1993; Bray and Lawrence, 1992). Another method commonly used to demonstrate capacitation is the in vitro induction of the acrosomal reaction, called spermatozoal activation. This method uses egg water (EW), a

\footnotetext{
* Corresponding author. Tel.: + 5553 32368132; fax: + 555332368042.

E-mail address: andrebraga_pa@yahoo.com.br (A. Braga).
}

flocculent material released throughout spawning that is composed of the outermost layer of the egg, the vitelline envelope, cortical rods and some thelycal substances. Spermatozoa are activated by contact between the cells and the EW (Kruevaisayawan et al., 2008). Alfaro et al. (2003) evaluated spermatozoal activation by this method using spermatophores collected from the terminal ampoules of $L$. occidentalis, $T$. byrdi and $X$. riveti. The activation rates were low or zero, supporting the hypothesis that spermatozoa cannot fertilize oocytes when spermatophores are not previously stored in or adhered to the thelycum. Similar results were reported for L. vannamei, L. stylirostris and S. ingentis (Alfaro et al., 2007; Wikramanayake et al., 1992).

Morphological changes associated with capacitation have been identified via ultrastructural studies of spermatozoa. For example, the ultrastructure of spermatozoal capacitation in shrimp has been described for S. ingentis, L. vannamei, L. stylirostris and L. occidentalis (Alfaro et al., 2007; Aungsuchawan et al., 2011; Wikramanayake et al., 1992).

There is limited information on spermatozoal capacitation in shrimp, which hinders an understanding of this process and its application to aquaculture. Post-larvae production of shrimp requires that the spermatophore be incubated in the thelycum, and this has prevented shrimp in vitro reproduction in laboratories. Understanding capacitation could be useful to the development of biotechnologies that would allow spermatozoal induction without spermatophore storage into the thelycum. 
Farfantepenaeus paulensis is a marine shrimp that is used in Brazilian aquaculture. Post-larvae of the species have been produced since the 80 s, and technological advances have facilitated the reproduction of F. paulensis in captivity, which has allowed the commercial production of $F$. paulensis in pen enclosures in the Patos Lagoon estuary (southern Brazil) in the last decade (Marchiori and Boff, 1983; Peixoto et al., 2011; Poersch et al., 2006).

The spermatozoal ultrastructure has been the subject of some research (Braga et al., 2013); however, the ultrastructure of the spermatozoal capacitation for $F$. paulensis is still unknown. Thus, the aim of this study was to evaluate the ultrastructural changes experienced by $F$. paulensis spermatozoa after the spermatophore is stored in the thelycum. This study is the first morphological description of the capacitation process for a closed-thelycum penaeid species.

\section{Material and methods}

\subsection{Animals and biological material sampling}

Farfantepenaeus paulensis broodstock $(\mathrm{n}=50)$ were collected in Santa Catarina $\left(26^{\circ} 54^{\prime} \mathrm{S} 48^{\circ} 34^{\prime} \mathrm{W}\right)$ offshore and transferred to the Marine Station of Aquaculture at the Federal University of Rio Grande, Southern Brazil. In the lab, the animals were acclimated for one week in one $10 \mathrm{~m}^{2}$ circular maturation tank (5000 L). During this period, the shrimp were fed four times daily with crab, squid, fish and the commercial diet (Breed-S Inve Aquaculture, Belgium) offered ad libitum alternately. The seawater ( $30 \pm 1 \mathrm{ppt}$ ) was renewed daily at a $100 \%$ rate and maintained at $27 \pm 1{ }^{\circ} \mathrm{C}$. Food remains, feces and exuviae were removed from the tank daily. The artificial photoperiod was 14:10 light: dark.

After acclimation, naturally coupled females $(53.04 \pm 8.21 \mathrm{~g})$ were identified by visual examination of the thelycum and were unilaterally eyestalk ablated and maintained under the same acclimation conditions. The gonads were examined daily using a flashlight to illuminate the ovaries in contrast to the white bottom of the maturation tank. Mature females ( $n=8$ ) were identified (Peixoto et al., 2003), and the spermatophore stored in the thelycum of each female was removed by dissection. Simultaneously, eight males $(22.75 \pm 4.11 \mathrm{~g})$ in the intermolt stage were selected from among the population of broodstocks. Their spermatophores were manually extruded via compression of the coxae of the fifth pereiopod pair (Nakayama et al., 2008). Spermatophores collected from both the terminal ampoule and thelycum were fixed in 1:1:1 6\% glutaraldehyde, $6 \%$ paraformaldehyde, and 0.1 M sodium cacodylate solution ( $\mathrm{pH} 7.2$ ). The samples were maintained at $4{ }^{\circ} \mathrm{C}$ for $24 \mathrm{~h}$ and were then transferred to the Immunology and Electronic Microscopy Laboratory at the Brazilian Enterprise for Agricultural Research.

\subsection{Transmission electron microscopy (TEM)}

The samples were washed three times for 15 min each in $0.1 \mathrm{M}$ sodium cacodylate and $0.2 \mathrm{M}$ sucrose and post-fixed for $3 \mathrm{~h}$ in $1 \%$ osmium tetroxide at $4{ }^{\circ} \mathrm{C}$. After this period, the samples were washed two times for $15 \mathrm{~min}$ in bi-distilled water and were dehydrated in ethanol solutions of increasing concentration (30\%, 50\%, 70\%, 90\%, 95\% and 100\%). Following dehydration, the samples were immersed three times for $10 \mathrm{~min}$ in acetone and dyed with $1 \%$ methylene blue in $1 \%$ borax. The samples were maintained in 1:1 epoxy resin (Epon $812 \AA$ ):acetone for $1 \mathrm{~h}$ under continuous stirring, embedded in epoxy resin for an additional hour and finally blocked. The blocks remained for 5 days at $60{ }^{\circ} \mathrm{C}$.

Thin sections $(100 \mathrm{~nm})$ were collected by ultramicrotomy (Leica Ultracut UCT). Some of these sections were selected under a light microscope (Olympus BX 51) and mounted on copper grids. These sections were examined with a Zeiss EM 900 transmission electron microscope.

\section{Results}

Fig. 1 shows the ultrastructural changes in spermatozoa after storage in thelycum. The spermatozoa collected from terminal ampoule (S-spermatozoa) consisted of a main body composed of a thin band of cytoplasm surrounding the nucleus and the basal region of the acrosomal region, which has an anterior acrosomal spike (Fig. 1A). This pattern is like the one observed in the spermatozoa collected from thelycum (T-spermatozoa) (Fig. 1D).

In both S- and T-spermatozoa, the cytoplasm was a thin bandposterior to the nucleus and anteriorly limited by the acrosomal region. The cytoplasmic band was composed of accumulated membranes and two populations of vesicles, one small and another large (Figs. 1B, E).

The nuclear region of S- and T-spermatozoa had remarkable ultrastructural differences. The nucleus in the S-spermatozoa showed uncondensed chromatin made up of a granule network and filaments, which assigns to it a fibrous pattern (Fig. 1B). This nuclear pattern was also observed in the T-spermatozoa (Fig. 1E). However, the filaments that compose the nucleus were less abundant in the T-spermatozoa, and the region's pattern was therefore more electron-lucent (Figs. 1B, E).

Differences between S- and T-spermatozoa were also observed in the acrosomal region. The material that composes the acrosomal vesicle (i.e., acrosomal cap and spike) is more electron-dense in T-spermatozoa. In addition, the acrosomal cap is less concave in T-spermatozoa. The subacrosomal region was composed of flocculent material in S-spermatozoa, whereas it has a greater lateral extent and was composed of a denser material in T-spermatozoa (Fig. 1A, C, D, F).

\section{Discussion}

The morphological pattern of S-spermatozoa of $F$. paulensis observed in this study was congruent with that previously described for the species (Braga et al., 2013). However, remarkable differences were observed in spermatozoa after spermatophore storage in the thelycum. These differences were primarily related to the nuclear and acrosomal regions of the S-spermatozoa, and included the following: (1) the chromatin were less condensed; (2) the acrosomal region was more electron-dense; (3) the acrosomal cap was less concave; and (4) the subacrosomal region lost its flocculent appearance and was much more electron-dense.

In S. ingentis, the morphological changes after spermatophore storage into the thelycum are also associated with the acrosomal vesicle and the subacrosomal region. However, these changes are more complex than those observed in F. paulensis. For example, the S-spermatozoa of $S$. ingentis have externally spiraled spikes and the subacrosomal region is highly complex, composed of a crystalline lattice, a central granular core, a saucer-shaped plate and spherical bodies located in the granular core (Kleve et al., 1980; Medina et al., 1994). In the T-spermatozoa of S. ingentis, the spiral pattern of the spike is lost and a new structure in subacrosomal region is developed, known as the extended saucer (Wikramanayake et al., 1992).

Three basic differences have been described between the S- and T-spermatozoa of Litopenaeus species: (1) the subacrosomal region of T-spermatozoa shows denser filamentous material in comparison with S-spermatozoa; (2) chromatin fibers of T-spermatozoa are more de-condensed than those of the S-spermatozoa; and (3) a spiral line observed on the external surface of the spike and other circular basal line observed on the surface of the acrosomal cap of S-spermatozoa of L. vannamei are lost in T-spermatozoa (Alfaro et al., 2007; Aungsuchawan et al., 2011).

Although S. ingentis have a closed thelycum like F. paulensis, the ultrastructural changes undergone by spermatozoa of $F$. paulensis after capacitation were much like those described for the open-thelycum Litopenaeus (items 1 and 2 listed above). This similarity is directly associated with the morphological patterns of the acrosomal reaction of Sicyoniidae and Penaeidae. 

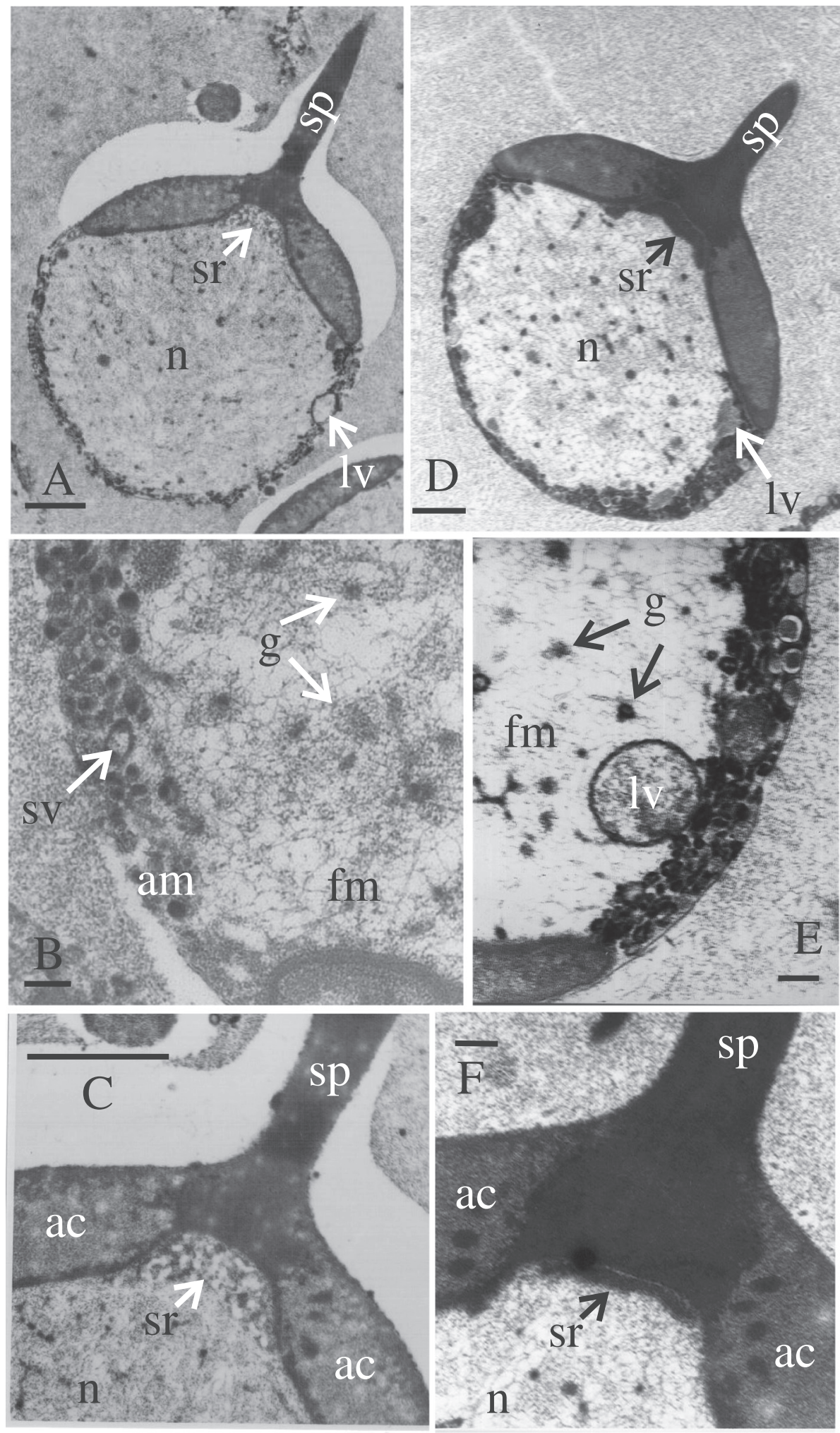

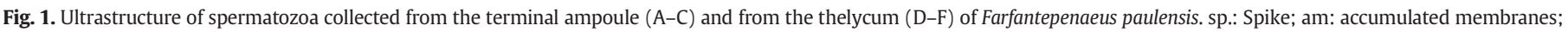
sv: small vesicle; lv: large vesicle; $\mathrm{n}$ : nucleus; g: granules; fm: filaments; ac: acrosomal cap; sr: subacrosomal region. Scale bars = A, B: 1.1 um; C: $0.15 \mu \mathrm{m}$; D: $0.6 \mu \mathrm{m}$; E, F: $0.25 \mu \mathrm{m}$.

In Sicyoniidae, the acrosomal reaction is a biphasic process that comprises the spike depolymerization followed by acrosomal exocytosis (phase 1); and the formation of the acrosomal filament (phase 2) (Griffin et al., 1988). Wikramanayake et al. (1992) suggested that the new structure formed in the T-spermatozoa of $S$. ingentis acts as a template for the extension of the acrosomal filament. However, the acrosomal reaction in the Penaeidae does not involve the formation of an acrosomal filament and consists only of spike depolymerization and the exocytosis of the cell contents (Kruevaisayawan et al., 2008; Pongtippatee et al., 2007). For this family, the subacrosomal region is known to be related to exocytosis because it becomes progressively denser and larger throughout the acrosomal reaction, forcing the 
rupture of the acrosomal vesicle (Alfaro et al., 2003, 2007; Pongtippatee et al., 2007). Thus, the morphological changes observed in the subacrosomal region of Litopenaeus species and F. paulensis after capacitation are most likely related to the function of this region during the acrosomal reaction.

Likewise in the subacrosomal region, the less condensed pattern of the chromatin fibers is most likely related to the acrosomal reaction. Shigekawa and Clark (1986) suggested that uncondensed chromatin is more elastic than condensed chromatin. Thus, it is possible that the less condensed nucleus in T-spermatozoa facilitates the exocytosis at the end of the penaeid acrosomal reaction. Limited information on the acrosomal reaction and the ultrastructure of the capacitation for Farfantepenaeus prevents a wider discussion on the other morphological changes identified for F. paulensis in this study.

The morphological changes of spermatozoa related to capacitation are most likely responses to ionic and biochemical changes that occur while the spermatophore is stored in the thelycum (Wikramanayake et al., 1992). For example, an increased $\mathrm{pH}$ and more $\mathrm{Ca}^{+2}$ have been reported in capacitated spermatozoa of S. ingentis (Griffin et al., 1987; Lindsay and Clark, 1992). However, Lindsay and Clark (1992) reported that the ionic changes may not be the trigger for morphological changes throughout capacitation and acrosomal reaction. Instead, they may activate biochemical pathways that lead to morphological rearrangements.

Some biochemical changes have been described in penaeid spermatozoa after capacitation. For example, Vanichviriyakit et al. (2004) found different profiles of protein and lipid membranes in S- and Tspermatozoa of Penaeus monodon. According to the authors, these biochemical changes were the result of the interaction between thelycal protein and spermatozoal membrane extractives, e.g., thelycal components are adsorbed to spermatozoal membrane, whereas molecules present on the spermatozoal surface are removed during the time spermatophores are stored in the thelycum.

In mammals, the tyrosine phosphorylation is considered biochemical evidence of the spermatozoal capacitation (Cross, 1998; Davis, 1981; Visconti et al., 1999). Vanichviriyakit et al. (2004) also reported the sequential increase of tyrosine phosphorylation in spermatozoa of $P$. monodon throughout spermatophore storage in the thelycum. Aungsuchawan et al. (2011) demonstrated that the site of the phosphorylation in L. vannamei changes from the spike in S-spermatozoa to the subacrosomal region in T-spermatozoa. It is possible that this change is related to the morphological changes in the subacrosomal region that have been reported for F. paulensis and other shrimp. However, further studies on the morphological and biochemical changes are required to understand the mechanisms of spermatozoal capacitation and eventually allow the in vitro production of penaeid larvae.

\section{Conclusions}

After the spermatophore is stored in the thelycum, the spermatozoa of $F$. paulensis undergo morphological changes related to capacitation. Stored spermatozoa have less condensed chromatin and the acrosomal region is more electron-dense and less concave. The most remarkable morphological change observed in the spermatozoa of $F$. paulensis was the loss of the flocculent appearance of the subacrosomal region, which became much denser in capacitated spermatozoa.

\section{Acknowledgments}

The authors are grateful for the financial support provided by the National Council for Scientific and Technological Development (CNPq), the Ministry of Fishery and Aquaculture (MPA) and the Coordination for the Improvement of Higher Level Personnel (CAPES). A. Braga, W.J. Wasielesky and L.H. Poersch are research fellows of CNPq.

\section{References}

Alfaro, J.M., Lawrence, A.L., Lewis, D., 1993. Interaction of bacteria and male reproductive system blackening disease of captive Penaeus setiferus. Aquaculture 117, 1-8.

Alfaro, J.M., Muñoz, N., Vargas, M., Komen, J., 2003. Induction of sperm activation in open and closed thelycum penaeoid shrimps. Aquaculture 216, 371-381.

Alfaro, J., Ulate, K., Vargas, M., 2007. Sperm maturation and capacitation in the open thelycum shrimp Litopenaeus (Crustacea: Decapoda: Penaeoidea). Aquaculture 270, 436-442.

Aungsuchawan, S., Browdy, C.L., Withyachumnarnkul, B., 2011. Sperm capacitation of the shrimp Litopenaeus vannamei. Aquac. Res. 42, 188-195.

Braga, A., Nakayama, C.L., Suita de Castro, L., Wasielesky, W., 2013. Spermatozoa ultrastructure of the pink shrimp Farfantepenaeus paulensis (Decapoda: Dendrobranchiata). Acta Zool. 94, 119-124

Bray, W.A., Lawrence, A.L., 1992. Reproduction of Penaeus species in captivity. In: Fast, A., Lester, L.J. (Eds.), Marine Shrimp Culture: Principles and Practices. Elsevier Science Publishers B.V., The Netherlands, pp. 93-169.

Cross, N.L., 1998. Role of cholesterol in sperm capacitation. Biol. Reprod. 59, 7-11.

Davis, B.K., 1981. Timing of fertilization in mammals: sperm cholesterol/phospholipid ratio as a determinant of the capacitation interval. Proc. Natl. Acad. Sci. U. S. A. 78 (12), 7560-7564.

Griffin, F.J., Clark, W.H., Crowe, J.H., Crowe, L.M., 1987. Intracellulare pH decrease during the in vitro induction of the acrosome reaction in the sperm of Sicyonia ingentis. Biol. Bull. 173, 311-323.

Griffin, F.J., Shigekawa, K., Clark, W.H., 1988. Formation and structure of the acrosomal filament in the sperm of Sicyonia ingentis. J. Exp. Zool. 246, 94-102.

Kleve, M.G., Yudin, A.L., Clark, W.H., 1980. Fine structure of the unistellate sperm of the shrimp, Sicyonia ingentis (Natantia). Tissue Cell 12, 29-45.

Kruevaisayawan, H., Vanichviriyakit, R., Weerachatyanukul, W., Iamsaard, S., Withyachumnarnkul, B., Basak, A., Tanphaichitr, N., Sobhon, N., 2008. Induction of the acrosome reaction in black tiger shrimp, Penaeus monodon, requires sperm trypsin-like enzyme activity. Biol. Reprod. 79 (1), 134-141.

Lindsay, L.L., Clark, W.H., 1992. Preloading of micromolar intracellular $\mathrm{Ca}^{+2}$ during capacitation of Sicyonia ingentis sperm, and the role of the $\mathrm{pH}_{\mathrm{i}}$ decrease during the acrosome reaction. J. Exp. Zool. 262 (2), 219-229.

Marchiori, M.A., Boff, M.H., 1983. Induced maturation, spawning and larvae culture of the pink shrimp Penaeus paulensis Pérez-Farfante, 1967. Memorias de la Asociacion Latinoamericana Acuicultura 5, 331-337.

Medina, A. La Rosa, I.L, Santos, A. 1994. Ultrastructural comparison of the spermatozoa of Sicyonia carinata (Sicyoniidae) and Penaeopsis serrata (Penaeidae) shrimp (Crustacea, Dendrobranchiata), with particular emphasis on the acrosomal structure. J. Submicrosc Cytol. Pathol. 26 (3), 395-403.

Nakayama, C., Peixoto, S., Lopes, D., Vita, G., Krummenauer, D., Foes, G., Cavalli, R.O. Wasielesky, W., 2008. Métodos de extrusão manual e elétrica dos espermatóforos de reprodutores selvagens do camarão-rosa Farfantepenaeus paulensis (Decapoda: Penaeidae). Ciência Rural 38 (7), 2018-2022.

Peixoto, S., Cavalli, R.O., D'Incao, F., Milach, A.M., Wasielesky, W., 2003. Ovarian maturation of wild Farfantepenaeus paulensis in relation to histological and visual changes. Aquac. Res. 34, 1255-1260.

Peixoto, S., Wasielesky, W., Cavalli, R.O., 2011. Broodstock maturation and reproduction of the indigenous pink shrimp Farfantepenaeus paulensis in Brazil: an updated review on research and development. Aquaculture 315, 9-15.

Poersch, L., Cavalli, R.O., Wasielesky, W., Castello, J.P., Peixoto, S., 2006. Perspectivas para o desenvolvimento dos cultivos de camarões marinhos no estuário da Lagoa dos Patos, RS. Ciência Rural 36, 1337-1343.

Pongtippatee, P., Vanichviriyakit, R., Chavadej, J., Plodpai, P., Pratoomchart, B., Sobhon, P. Withyachumnarnkul, B., 2007. Acrosome reaction in the sperm of the black tiger shrimp Penaeus monodon (Decapoda, Penaeidae). Aquac. Res. 38, 1635-1644.

Shigekawa, K., Clark, W.H., 1986. Spermiogenesis in the marine shrimp, Sicyonia ingentis. Dev. Growth Differ. 28 (2), 95-112.

Vanichviriyakit, R., Kruevaisayawan, H., Weerachatyanukul, W., Tawipreeda, P. Withyachumnarnkul, B., Pratoomchat, B., Chavadej, J., Sobhon, P., 2004. Molecular modification of Penaeus monodon sperm in female thelycum and its consequente responses. Mol. Reprod. Dev. 69, 356-363.

Visconti, P.E., Bailey, J.L., Moore, G.D., Pan, D., Olds-Clarke, P., Kopf, G.S., 1995. Capacitation of mouse spermatozoa. I. Correlation between the capacitation state and protein tyrosine phosphorylation. Development 121,1129-1137.

Visconti, P.E., Ning, X.P., Fornés, M.W., Alvarez, J.G., Stein, P., Connors, S.A., Kopf, G.S., 1999 Cholesterol efflux-mediated signal transduction in mammalian sperm: cholestero release signals and increase in protein tyrosine phosphorylation during mouse sperm capacitation. Dev. Biol. 214, 429-443.

Wikramanayake, A.H., Uhlinger, K.R., Griffin, F.J., Clark, W.H., 1992. Sperm of the shrimp Sicyonia ingentis undergo a bi-phasic capacitation accompanied by morphology changes. Dev. Growth Differ. 34 (3), 347-355. 